\title{
IMPLEMENTASI SISTEM INFORMASI PENGELOLAAN DATA TRANSAKSI PENJUALAN DAN PERSEDIAAN PRODUK HASIL BUMI DENGAN MENGGUNAKAN BAHASA PEMROGRAMAN PERSONAL HOME PAGE DAN DATABASE MYSQL
}

(Studi Kasus : UD. Usaha Hasil Bumi)

\author{
Irzal Arief Wisky ${ }^{1}$ \\ ${ }^{1}$ Fakultas Ilmu Komputer, Universitas Putra Indonesia YPTK Padang \\ e-mail : irzal.arief12@gmail.com
}

\begin{abstract}
Penelitian ini membahas tentang implementasi aplikasi untuk pengolahan transaksi penjualan dan persediaan barang pada UD. Usaha Hasil Bumi dengan menggunakan bahasa pemrograman PHP (personal Home Page) dan database MYSQL. Dengan melakukan analisis terhadap data yang telah dikumpulkan dengan menggunakan alat bantu perancangan sistem, hasil dari analisis tersebut diterapkan ke dalam suatu aplikasi yang mampu mengelola tentang penjualan dan persediaan barang, sehingga dapat membantu pihak UD. Usaha Hasil Bumi dalam pengolahan transaksi penjualan dan persediaan barang yang lebih efektif dan efesien.
\end{abstract}

Keywords : Implementasi, Penjualan, Persediaan, PHP Dan MYSQL.

\section{PENDAHULUAN}

Perkembangan ilmu pengetahuan dan penerapan teknologi mengalami peningkatan. Efektifitas serta efisiensi waktu dan biaya menyebabkan setiap praktisi bisnis merasa perlu menerapkan teknologi dalam setiap lingkungan kerjanya. Pada saat ini teknologi yang banyak dimanfaatkan di berbagai instansi pemerintah dan swasta.

Pengolahan data yang dimaksud bertujuan untuk menghasilkan informasi yang berguna bagi perusahaan untuk melakukan pengambilan keputusan manajemen demi kemajuan perusahaan tersebut. Suatu Informasi dapat dikategorikan berguna jika informasi itu tepat waktu dalam penyampaiannya dan pengguna dapat dengan mudah melakukan akses dari informasi tersebut, serta dengan pengolahan data akan menghasilkan informasi yang bersifat akurat,cepat, dan up to date.

\subsection{Perumusan Masalah}

Adapun rumusan masalah yang dapat dirumuskan dari tujuan penelitian ini di antaranya:

1. Apakah sistem informasi pengolahan data pada UD. Usaha Hasil Bumi dapat menghasilkan informasi dan laporan seperti laporan data barang, laporan pembelian, laporan penjualan barang yang tepat dan akurat?

2. Apakah sistem yang dirancang dengan menggunakan bahasa pemograman PHP dan database MYSQL dapat meningkatkan kinerja dan mempercepat pemrosesan kegiatan transaksi penjualan di UD. Usaha Hasil Bumi?

\section{LANDASAN TEORI}

\subsection{Konsep Dasar Sistem Informasi}

Konsep dasar sistem informasi adalah suatu sistem di dalam suatu organisasi yang mempertemukan kebutuhan pengolahan transaksi harian, mendukung operasi, bersifat manajerial dan kegiatan strategi dari suatu organisasi dan menyediakan pihak luar tertentu dengan laporan- laporan yang diperlukan. (Tata Sutabri, 2012)

\subsection{Definisi Sistem}

Definisi sistem berkembang sesuai dengan konteks dimana pengertian sistem itu digunakan. suatu sistem dapat diartikan sebagai suatu kumpulan atau himpunan dari unsur, komponen, atau variabel yang terorganisir, saling berinteraksi, saling 
tergantung satu sama lain dan terpadu. (Tata Sutabri,2012)

\subsection{Pengertian Informasi}

Informasi merupakan aset penting bagi suatu institusi atau organisasi. Oleh karena itu, informasi harus berkualitas, dijaga, dan dipelihara dengan baik. Sedangkan kualitas dari suatu informasi tergantung dari tiga hal yaitu :akurat, relevan dan tepat waktu. (Hamim Tohari,2014)

\subsection{Metode Economic Order Quantity (EOQ)}

Metode EOQ merupakan metode yang digunakan untuk menentukan jumlah pembelian bahan mentah pada setiap kali pesan dengan biaya paling rendah. (Carlen Valerle,2011)

Alasan-alasan untuk menyimpan persediaan (baik bahan baku maupun barang jadi), yang mana hal ini sejalan dengan prinsip EOQ, yaitu :

1. Untuk menghadapi ketidakpastian dalam permintaan sebagaimana diketahui bahwa adanya kemungkinan permintaan yang berfluktuasi, sehingga dapat memuaskan permintaan pelanggan.

2. Untuk menghindari fasilitas manufaktur yang tidak bisa bekerja lagi karena adanya kegagalan mesin, suku cadang yang tidak tersedia, dan pengiriman suku cadang yang terlambat.

3. Untuk mengambil keuntungan dari diskon-diskon.

4. Untuk berjaga-jaga jika terjadi kenaikan harga di masa akan datang.

Rumus yang di gunakan metode EOQ ini sebagai berikut :

$\mathrm{EOQ}=\mathrm{Q}^{*}=\frac{\sqrt{2 C R}}{\mathrm{H}}$

Keterangan:

$\mathrm{Q}^{*}=$ Jumlah/nilai EOQ (unit).

$\mathrm{C}=$ Biaya pemesanan per pesan.

$\mathrm{R}=$ pemintaan per periode (unit)

$\mathrm{H}=$ Biaya Penyimpanan.

\subsection{Siklus Hidup Pengembangan Sistem}

Pengembangan sistem dapat berarti menyusun suatu sistem yang baru untuk mengganti sistem yang lama secara keseluruhan atau memperbaiki sistem yang ada.

Berikut Siklus Hidup Perkembangan Sistem dapat dilihat pada gambar 2.1:

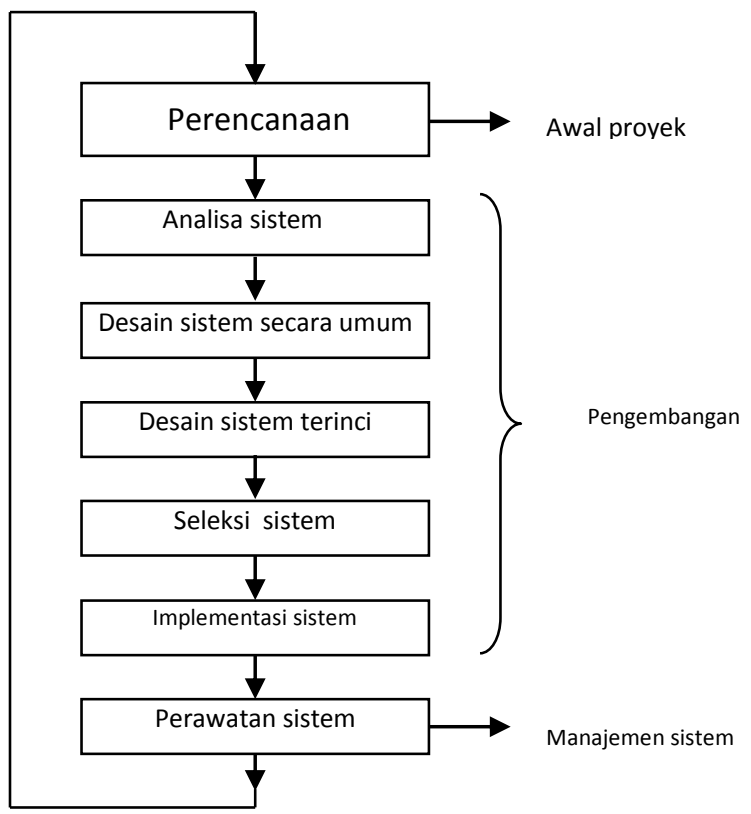

(Sumber: Hanim Tohari, 2011)

Gambar 2.1 Siklus Hidup Pengembangan Sistem

\section{ANALISA DAN HASIL}

\subsection{Aliran Sistem Informasi Lama}

Pada aliran Sistem Informasi penjualan dan pengolahan data persediaan barang pada UD. Usaha Hasil Bumi yang lama terdapat kelemahan yang menyebabkan kesalahan dan kesulitan, serta kinerja dari sistem yang kurang optimal dalam menghasilkan informasi yang akurat.

Adapun Aliran Sistem Informasi penjualan dan persediaan barang (Stock) UD. Usaha Hasil Bumi yang lama dapat dilihat pada gambar 3.1.

\subsection{Aliran Sistem Informasi (ASI) Baru}

Bagian ini merupakan kerangka dasar yang ditunjukan sebagai bahan usulan untuk mengembangkan sistem yang baru. Sistem yang baru ini akan memperbaiki kerja sistem pengolahan data tanpa menganggu stabilitas sistem. Dalam hal ini penulis mencoba membuat suatu sistem baru dari pengembangan yang ada, berupa Aliran Sistem Informasi (ASI) Baru, sepertiterlihat pada gambar 3.2. 


\subsection{Context Diagram}

Context Diagram adalah gambaran umum tentang suatu sistem yang terdapat dalam suatu organisasi yang memperlihatkan batasan (boundry) sistem, adanya interaksi antara eksternal entity dengan suatu sistem dan informasi secara umum mengalir diantara entity dan sistem. Context diagram ini merupakan alat bantu yang digunakan dalam menganalisa sistem yang akan dikembangkan.

Untuk mendapatkan gambaran mengenai sistem baru yang diusulkan serta memperjelas ruang lingkup penulisan maka perlu dijabarkan context diagram pada gambar 3.3

\subsection{Data Flow Diagram Level 0}

Data Flow Diagram level 0 merupakan penjabaran dari context diagram seperti dapat dilihat pada gambar 3.4 :

\subsection{ERD ( Entity Relationship Diagram )}

Entity Relationship Diagram

Merupakan diagram yang menggambarkan hubungan antara entity dalam sebuah database. Pada diagram ini dapat dilihat hubungan antar file dalam sistem informasi persediaan barang (stock). Dari diagram ini juga dapat dilihat bagaimana satu entity dihubungkan dengan entity lain. Untuk lebih jelasnya ERD Sistem informasi persediaan barang (stock) dapat digambarkan seperti gambar 3.5.

\section{IMPLEMENTASI DAN HASIL}

\subsection{Implementasi Sistem}

Implementasi sistem merupakan tahap meletakkan sistem yang baru dikembangkan supaya nantinya sistem tersebut siap untuk dioperasikan sesuai dengan yang diharapkan. Implementasi juga merupakan penerapan dari elemen-elemen yang telah didesain dalam bentuk pemrograman untuk menghasilkan suatu tujuan yang dibuat berdasarkan kebutuhan terhadap hardware, software dan brainware.

1. Halaman Form Login

Halaman ini berfungsi untuk masuk ke dalam sistem,.Untuk lebih jelasnya dapat dilihat pada gambar 4.1.

\section{Halaman Entry Data Barang}

Halaman Entry Data Barang merupakan halaman administrator yang berfungsi untuk untuk mengentrikan data barang kedalam database. Untuk lebih jelasnya dapat dilihat pada gambar 4.2.

3. Halaman Entry Data Pelanggan

Halaman Entry Data Pelanggan merupakan halaman administrator yang berfungsi untuk untuk mengentrikan data pelanggan kedalam database. Untuk lebih jelasnya dapat dilihat pada gambar 4.3.

4. Entry Data Suplier

Halaman Entry Data Suplier merupakan halaman administrator yang berfungsi untuk untuk mengentrikan data suplier kedalam database. Untuk lebih jelasnya dapat dilihat pada gambar 4.4.

5. Entry Data Penjualan

Halaman Entry Data Penjualan merupakan halaman administrator yang berfungsi untuk untuk mengentrikan data penjualan kedalam database. Untuk lebih jelasnya dapat dilihat pada gambar 4.5

6. Analisa EOQ

Halaman Analisa EOQ merupakan halaman administrator yang berfungsi untuk untuk mengentrikan data EOQ kedalam database. Untuk lebih jelasnya dapat dilihat pada gambar 4.6.

7. Entry Data Pembelian

Halaman Entry Data Pembelian merupakan halaman administrator yang berfungsi untuk untuk mengentrikan data Pembelian kedalam database. Untuk lebih jelasnya dapat dilihat pada gambar 4.7

8. Faktur

Faktur adalah bukti penjualan barang yang diberikan kepada pelanggan. Untuk lebih jelasnya dapat dilihat pada gambar 4.8 .

9. Laporan Penjualan Bulanan

Laporan Penjualan bulanan adalah berisikan data-data tentang penjualan per bulan. Untuk lebih jelasnya dapat dilihat pada gambar 4.10.

10. Laporan Penjualan Tahunan

Laporan Penjualan tahunan adalah berisikan data-data tentang penjualan per tahun. Untuk lebih jelasnya dapat dilihat pada gambar 4.11. 


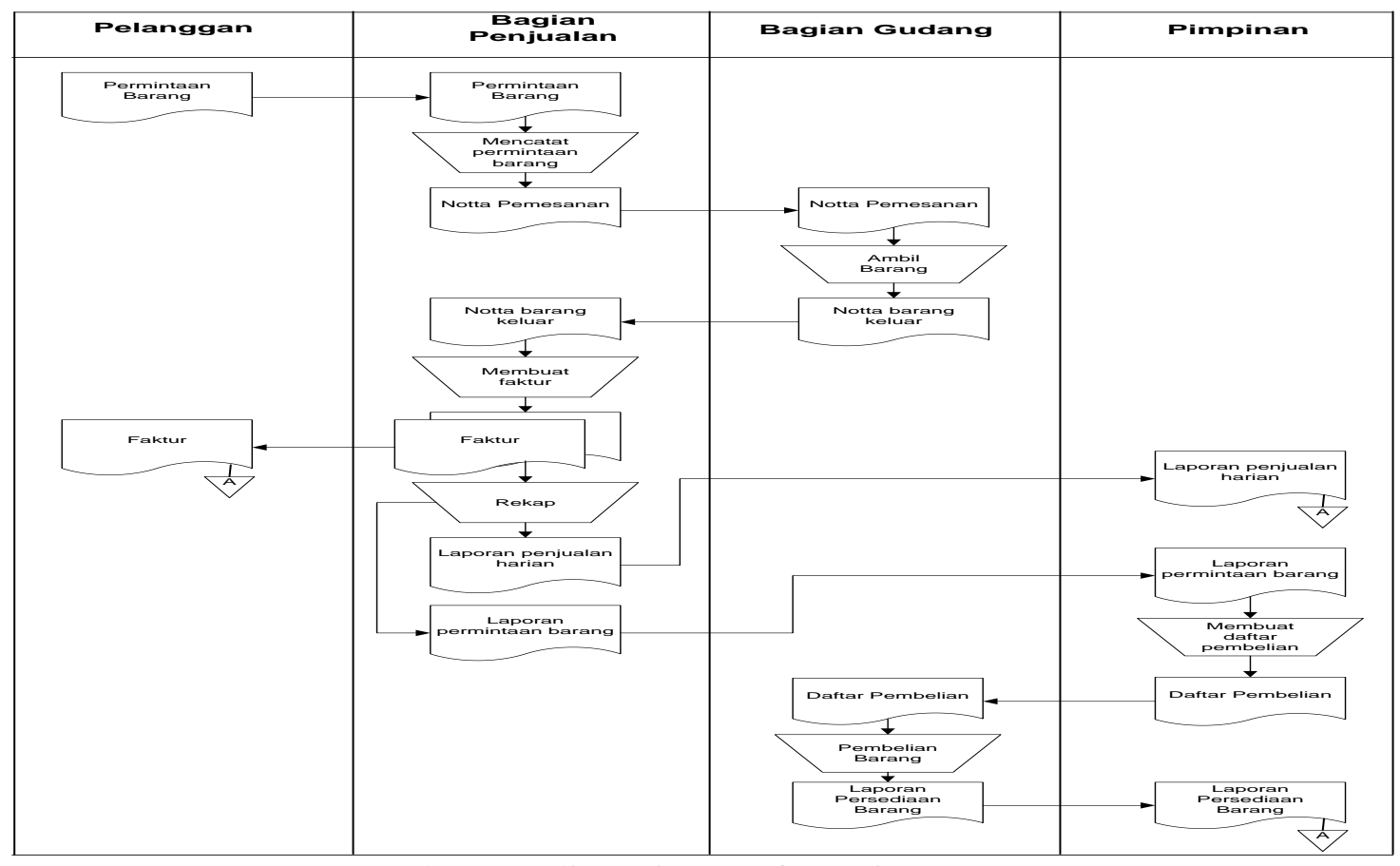

Gambar 3.1 Aliran Sistem Informasi (ASI) Lama

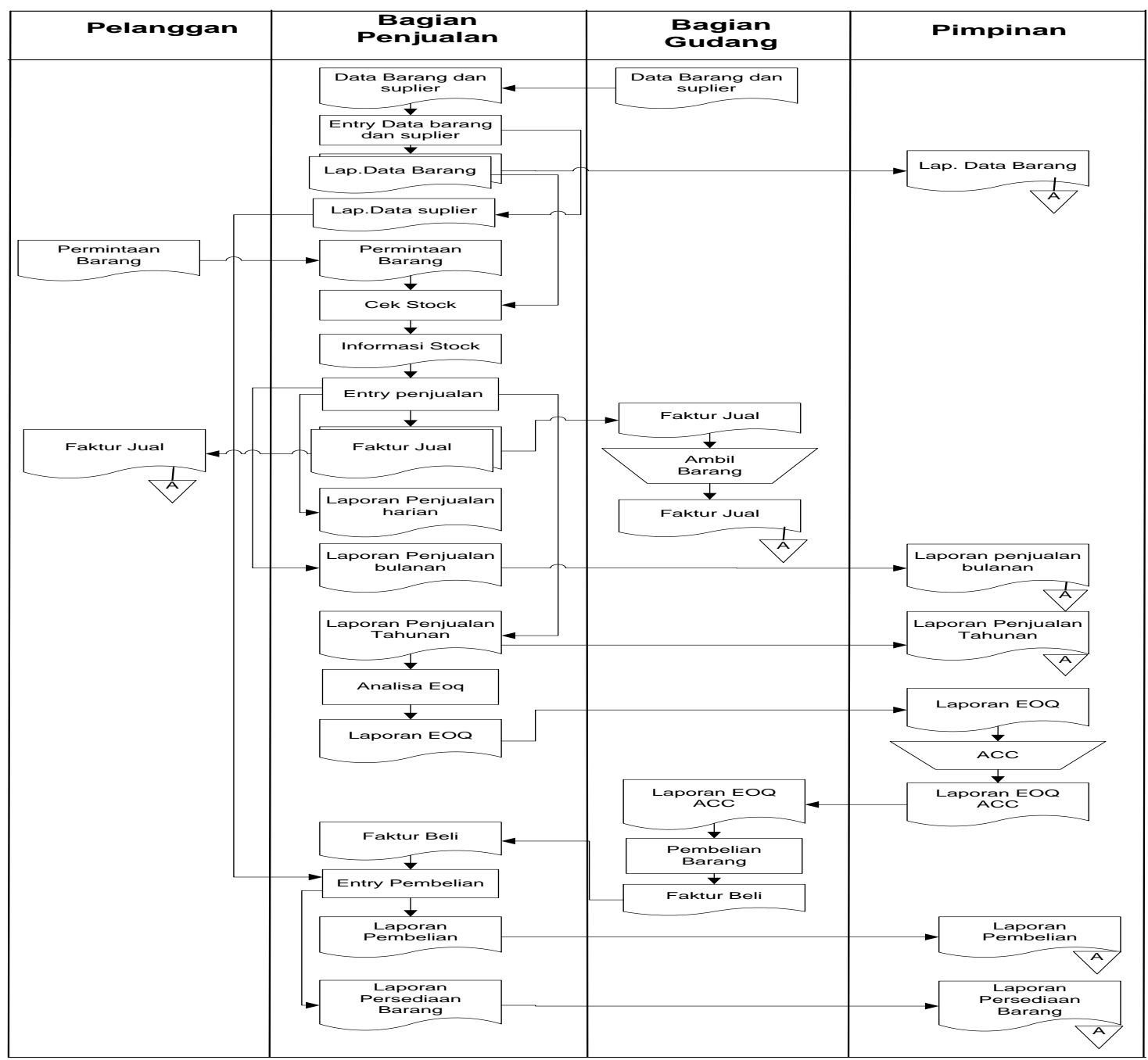

Gambar 3.2 Aliran Sistem Informasi (Asi) 


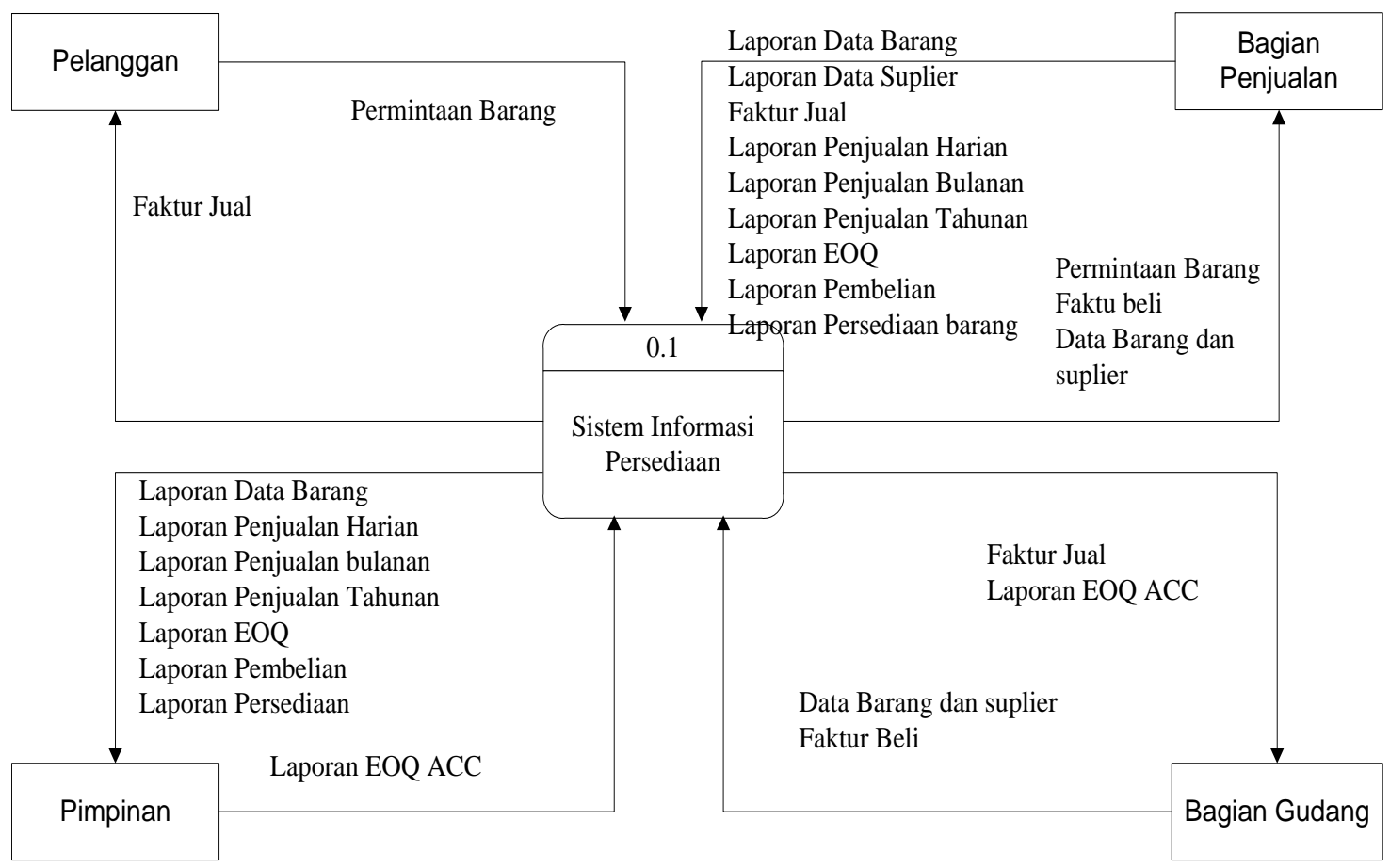

Gambar 3.3 Context Diagram Sistem Informasipersediaan barang (stock)

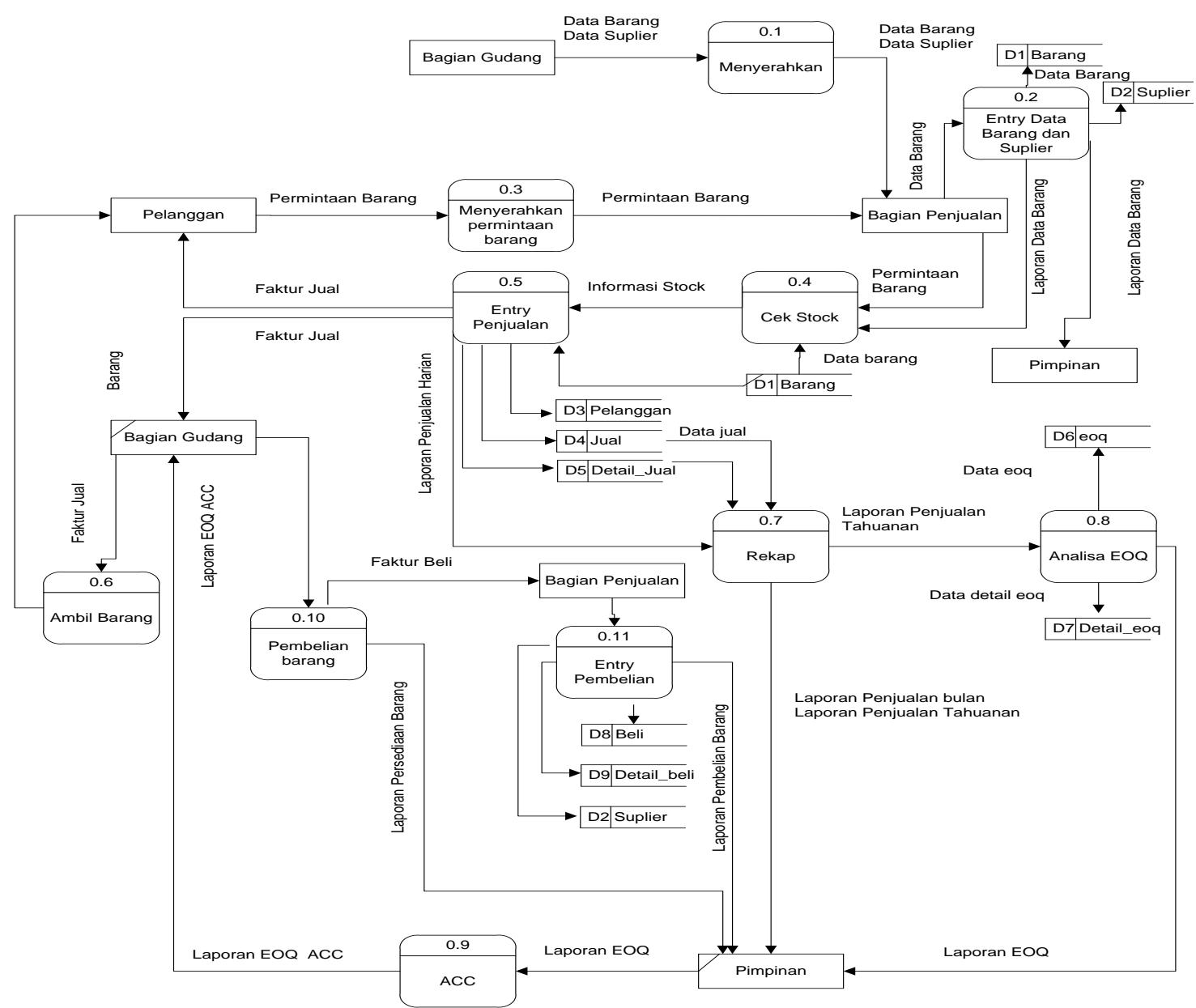

Gambar 3.4 Data Flow Diagram Level 0 


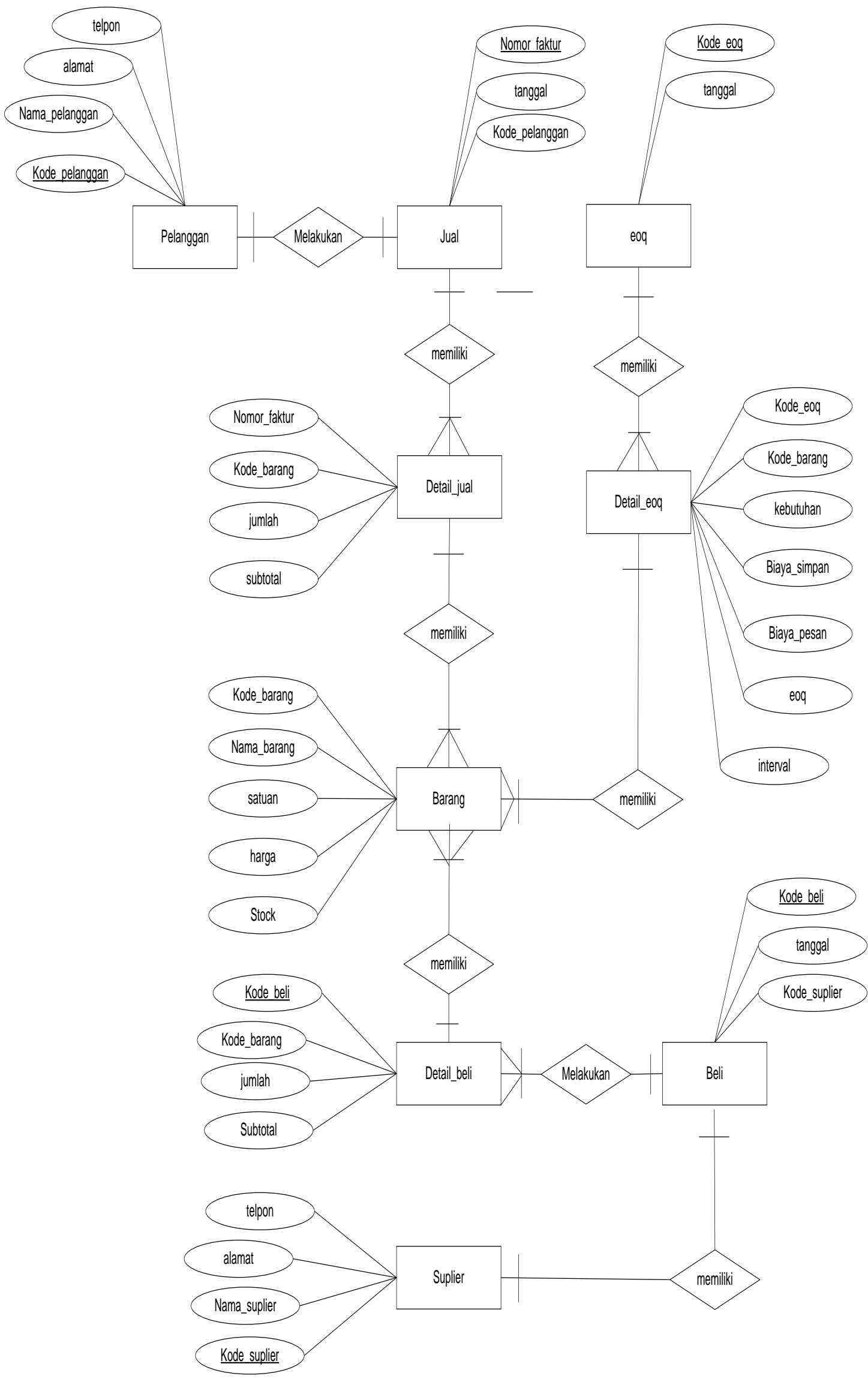

Gambar 3.5 Entity Relathionship Diagram (ERD) 
HALAMAN LOGIN

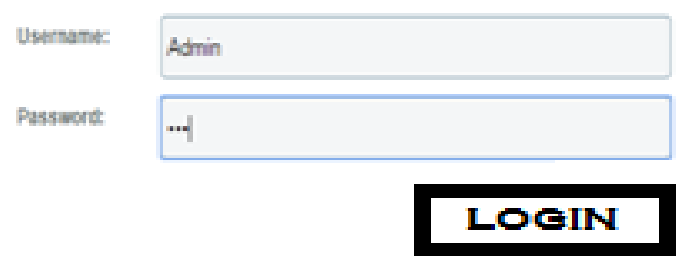

Gambar 4.1 Halaman Form Login

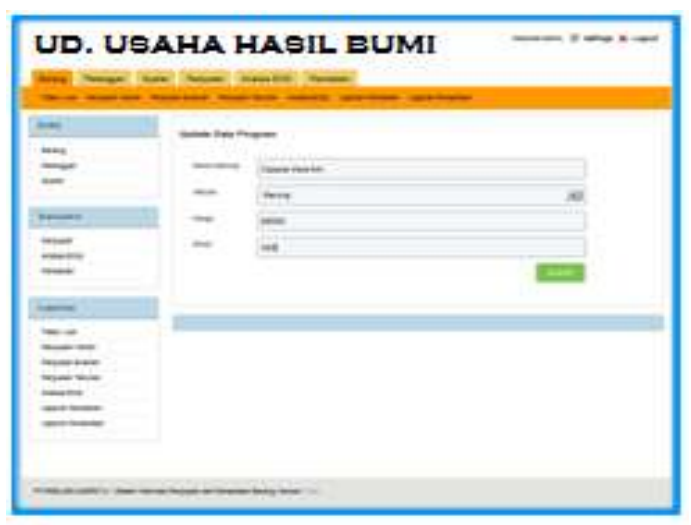

Gambar 4.2 Halaman Entry Data Barang

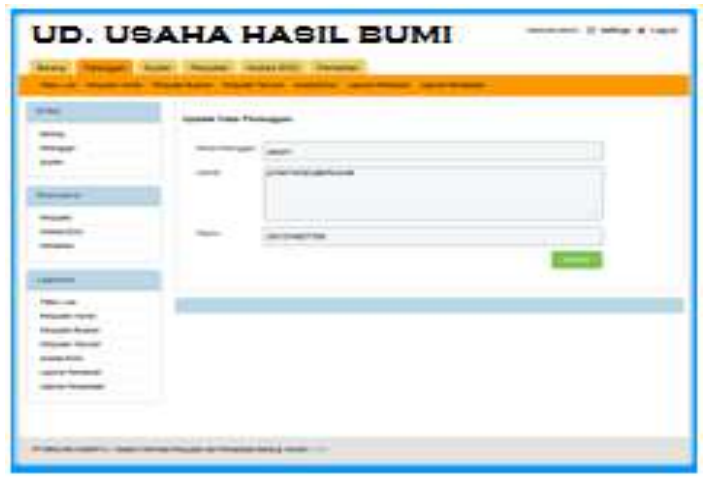

Gambar 4.3 Halaman Entry Data Pelanggan

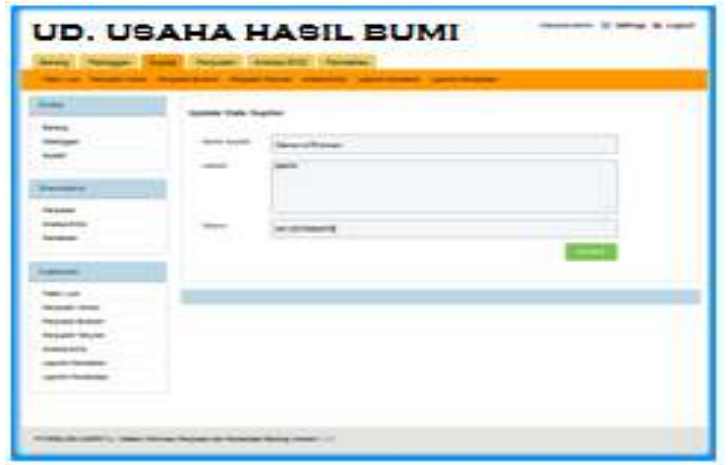

Gambar 4.4 Halaman Entry Data Suplier

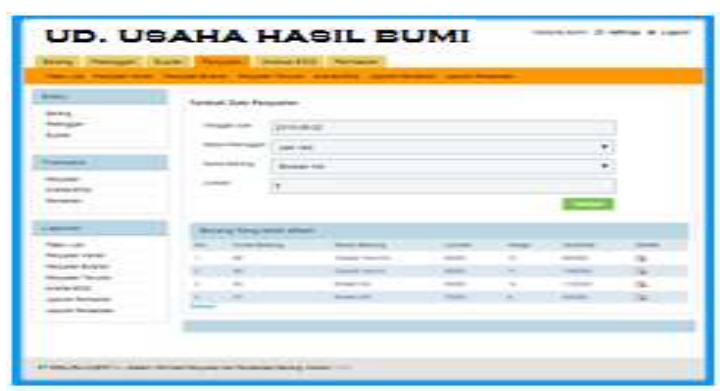

Gambar 4.5 Halaman Entry Data Penjualan

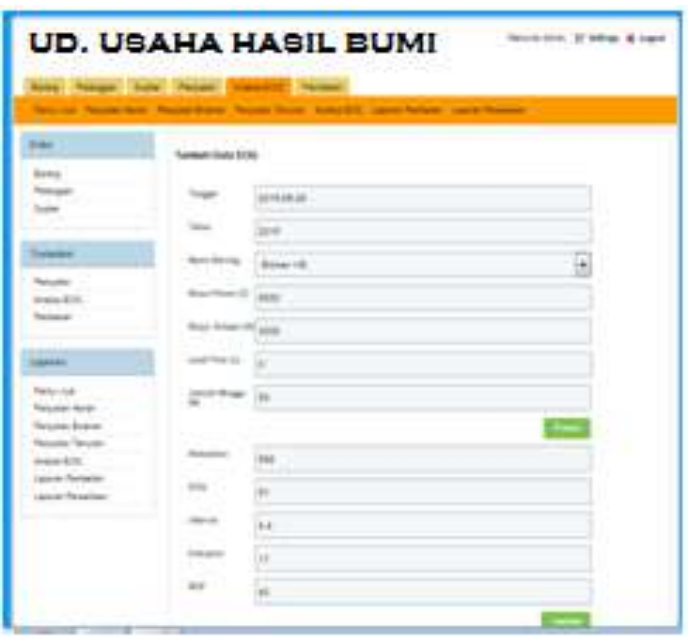

Gambar 4.6 Analisa EOQ

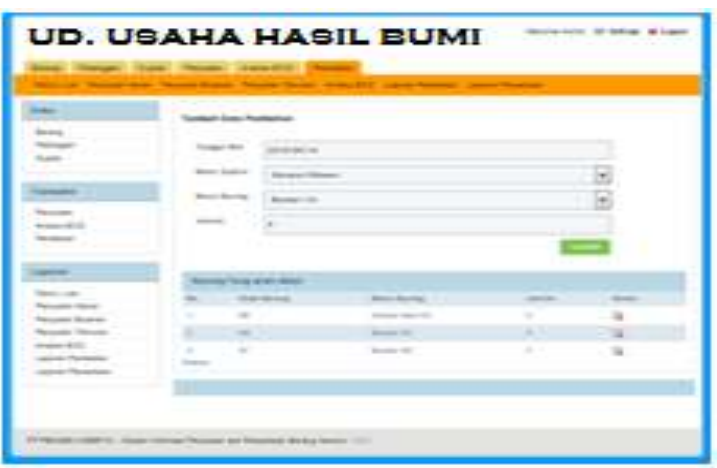

Gambar 4.7 Entry Data Pembelian

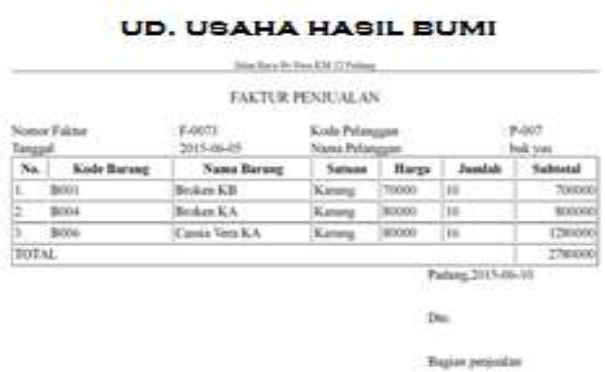

Gambar 4.8 Faktur 
UD. USAHA HABIL BUMI

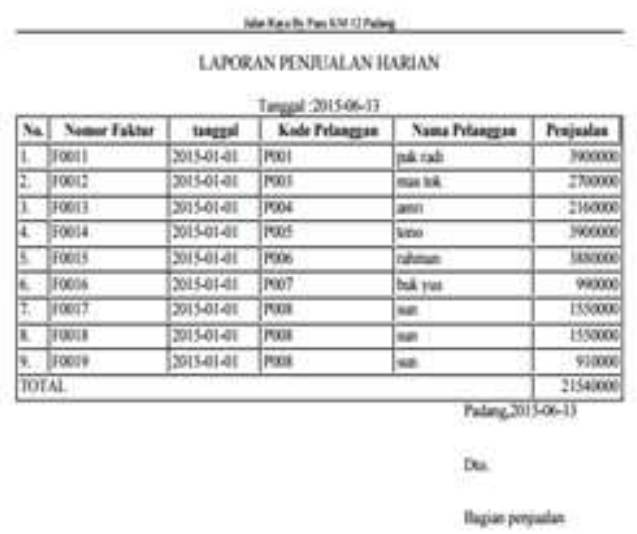

Gambar 4.9 Laporan Penjualan Harian

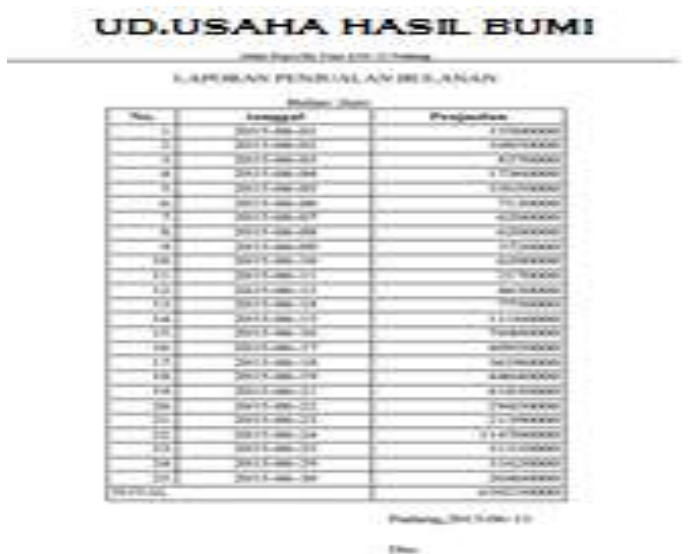

Gambar 4.10 Laporan Penjualan bulanan

UD. USAHA HASIL BUMI

anlouknowithe

LAPORAX PENULANTAIIXXS

\begin{tabular}{|c|c|c|}
\hline \multicolumn{3}{|c|}{ Thasis } \\
\hline $\mathrm{Ne}$ & ineal & Pajulate \\
\hline L & inran & 49600 \\
\hline 5 & Finur & $30 \times 0$ \\
\hline 3 & Xat: & 6130000 \\
\hline 4 & $\mathrm{Nanl}$ & $2 n \times n=0$ \\
\hline 5 & 40 & 156200 \\
\hline 5 & Ins & sostivand \\
\hline \multicolumn{2}{|c|}{$\overline{\mathrm{DNOAL}}$} & 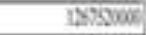 \\
\hline
\end{tabular}

De

Bepingopate

Gambar 4.11 Laporan Penjualan Tahunan
11. Laporan Data EOQ

Laporan Data EOQ adalah berisikan datadata tentang data EOQ. Untuk lebih jelasnya dapat dilihat pada gambar 4.12.

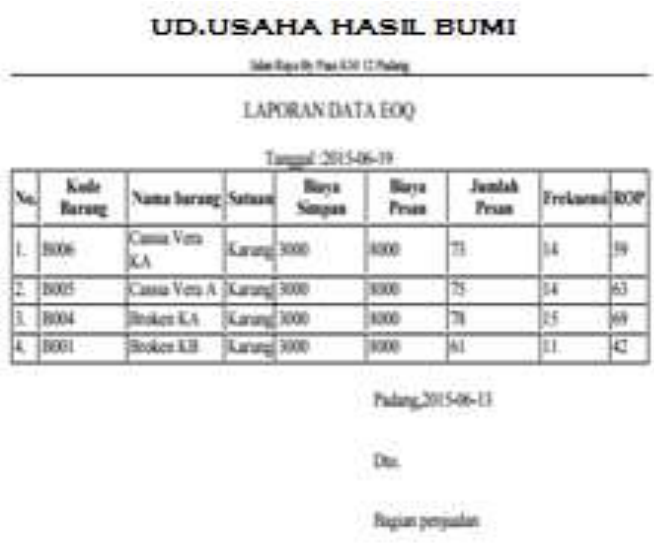

Gambar 4.12 Laporan Data EOQ

12. Laporan Data Pembelian

Laporan Data Pembelian adalah berisikan data-data tentang Pembelian. Untuk lebih jelasnya dapat dilihat pada gambar 4.13.

UD. UBAHA HABIL EUMI

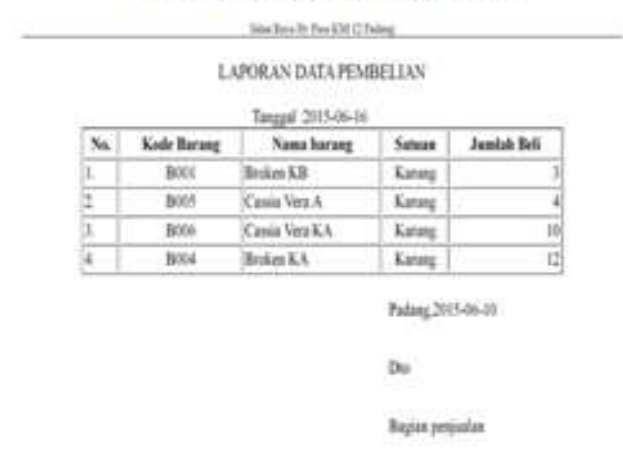

Gambar 4.13 Laporan Data Pembelian

\section{KESIMPULAN}

Berdasarkan atas penelitian yang telah penulis lakukan pada UD. Usaha Hasil Bumi, maka dapat diambil kesimpulan sebagai berikut :

1. Dengan adanya sistem baru dapat membantu perusahaan dalam menyelesaikan masalah pengolahan transaksi penjualan dan persediaan barang pada UD. Usaha Hasil Bumi.

2. Dengan adanya aplikasi sistem informasi baru dapat meningkatkan pelayanan dan kinerja. 


\section{DAFTAR PUSTAKA}

EMS, TIM.2014. Teori dan praktik PHPMySQL untuk Pemula, Jakarta : Elex Media Komputindo.

Fathansyah.2012. Basis Data edisi revisi. Bandung: INFORMATIKA Bandung.

Peranginangin, Kasiman. 2006. Aplikasi

WEB dengan PHP dan MySQL,

Yogyakarta : C.V ANDI OFFSET.

Rosa, Salahudin. 2011. Modul Pembelajaran Rekayasa Perangkat Lunak (terstruktur dan berorientasi objek), Bandung : modula

Sutabri,Tata. 2012. Konsep Sistem Informasi. Jakarta : Elex Media Komputindo.

Sibero,Alex.2010.Perancangan Web Aplikasi.Yogyakarta:Andi.

Sovia,Febio.2011.Membangun Aplikasi ELibrary Menggunakan HTML, PHP SCRIPT, dan MYSQL DATABASE, Jurnal Teknologi Informasi dan pendidikan vol. 3 No. 1 Maret 2011,ISSN : 2086 - 4981. 